\title{
Fysisk aktivitet, kropp og bevegelse i barnehagen
}

\author{
Kathrine Bjørgen og Olav Bjarne Lysklett \\ DMMH Dronning Mauds Minne Høgskole
}

Dette temanummeret i JASEd ble første gang markedsført på den første nettverkskonferansen for de som jobber med faget "Fysfos» i barnehagelærerutdanningen våren 2019. Deretter kom invitasjonen til å levere bidrag til temanummeret i september 2019 med tidsfrist innen 10. desember. Tidsskjemaet vårt sprakk, og våren 2020 inviterte vi noen utvalgte fagmiljøer til å levere utkast før sommerferien. Til slutt fikk vi inn ni artikler. Etter å ha tatt kontakt med fagfeller fra ulike fagmiljøer slapp vi fire artikler gjennom nåløyet, og alle disse er blitt vurdert av to fagfeller gjennom både en og to runder. De fire artiklene i dette temanummeret viser kompleksitet, bredde og dybde i ulike problemstillinger og metodiske fremgangsmåter i fagfeltet fysisk aktivitet, kropp og bevegelse i barnehagen.

Svært mange barn i Norden tilbringer mye av sin våkne tid i barnehagen. Barnehagen spiller en betydelig rolle i barns og foreldres liv, og er dermed viktig for samfunnet. I løpet av sine første leveår utvikler barn seg svært mye, og en stor del av denne utviklingen skjer gjennom bevegelse. Den enorme utviklingen som skjer fra småbarnsavdelingen, hvor barna stort sett kryper rundt på gulvet, til de blir skolestartere som springer rundt i skogen, vitner om store forandringer i barns bevegelsesrepertoar. Et temanummer om fysisk aktivitet, kropp og bevegelse i barnehagen er dermed et godt bidrag til forståelse om en viktig del av et menneskes liv. I dagens samfunn er det en økende bekymring for fysisk inaktivitet og økt stillesittende adferd blant barn og unge. Fokus på kunnskap om barns fysiske aktivitet er av den grunn også viktig.

Den nordiske barnehagemodellen legger stor vekt på at barna skal få være aktive, både inne og ute. Ifølge rammeplanen skal barnehagene legge til rette for at alle barn kan oppleve bevegelsesglede og mentalt og sosialt velvære, og dermed danne grunnlag for god fysisk og psykisk helse. Barna skal inkluderes i aktiviteter der de kan få være i bevegelse, lek og sosial samhandling og oppleve motivasjon og mestring ut fra egne forutsetninger. Vi har mindre kunnskap om hvordan det tilrettelegges for, og

^Korrespondanse: Kathrine Bjørgen, e-post: kbj@dmmh.no

(C) 2020 K. Bjørgen \& O. B. Lysklett. This is an Open Access article distributed under the terms of the Creative Commons Attribution 4.0 International License (https://creativecommons.org/licenses/by-nc/4.0/), allowing third parties to copy and redistribute the material in any medium or format and to remix, transform, and build upon the material for any purpose, even commercially, provided the original work is properly cited and states its license.

Citation: K. Bjørgen E O. B. Lysklett. "Fysisk aktivitet, kropp og bevegelse i barnehagen». Fournal for Research in Arts and Sports Education, Special Issue: Fysisk aktivitet, kropp og bevegelse i barnehagen, Vol. 4(2), 2020, pp. 1-6. 


\section{K. Bjørgen E̋ O. B. Lysklett}

om hvordan barn inkluderes i, fysisk aktivitet i barnehagen. Vi antar at gode opplevelser med fysisk aktivitet i barnehagealder kan gi gode vaner som varer livet ut. Det er behov for økt kunnskap om hvordan voksne kan være aktive, tilstedeværende og støtte og utfordre barna til variert kroppslig lek samtidig som de anerkjenner barnets mestring. I dette temanummeret blir det satt fokus på ulike tema relatert til fysisk aktivitet i barnehagen. Målet er at kunnskap fra artiklene når ut til ulike forskermiljø og til ansatte i barnehagen slik at kunnskapen kommer barnehagebarna til gode.

Fysisk fostring har i lang tid vært et fag i barnehagelærerutdanningen i Norge. I dag er faget innlemmet i et større fagområde: Natur, helse, bevegelse, som består av Fysisk fostring og Naturfag med miljølare. I de andre nordiske landene er det ikke organisert slik. I dag omfatter fagområdet fysisk aktivitet, bevegelse, kropp og helse, og dette er viktige tema i nordisk barnehagelærerutdanning. Fysisk og motorisk utvikling, samt tilrettelegging for at barnehagebarn skal kunne være fysisk aktive på egne premisser, er viktige momenter i dette fagområdet.

Barnehageforskning er i utvikling i hele Norden, samt i resten av verden. Mye av den skandinaviske forskningen på barnehageområdet er samlet på denne nettsiden: http://www.nb-ecec.org/no. Her kan en sortere forskningen på ulike tema; for eksempel får man 20 treff på «fysisk aktivitet» og 58 treff på «utendørsaktivitet». Norges forskningsråd er en av de som gir mest penger til forskning i Norge, og de har blant annet finansiert to store forskningsprogram knyttet til barnehagefeltet: Filiorum i Stavanger og BarnKunne i Bergen, begge etablert som to kraftsenter innen forskning på barnehagen. Dessverre har hverken Filiorum eller BarnKunne noe særlig fokus på fysisk aktivitet, kropp og bevegelse. To forskningsprosjekt som tar for seg fysisk aktivitet, kropp og bevegelse er bevilget penger fra Forskningsrådet. EnCompetence og $A C T N O W$ er prosjekter med store datainnsamlinger som vil komme fagfeltet vårt til gode. Her vil det nok komme mange spennende artikler og publikasjoner etter hvert, og tre av artiklene i dette temanummeret kommer fra disse fagmiljøene.

Innen vårt fagfelt tok det lang tid før noen skrev den første doktorgradsavhandlingen. Ingunn Fjørtoft disputerte i år 2000, og deretter tok det ti år før den neste doktorgraden kom. Etter 2010 har det heldigvis ikke tatt like lang tid før nye doktorgrader har blitt avlagt, og i 2020 er det to som har disputert. Vi vet at det kommer spennende doktorgrader i 2021 også, og håper den gode trenden fortsetter. Temanummeret er skrevet med tanke på et voksende felt av master- og ph.d.-studenter, forskere og lærerutdannete innen fagfeltet fysisk aktivitet, kropp og bevegelse i Norge og Norden. Vi håper temanummeret kan bidra til fornyet kunnskap, dialoger og diskusjoner innen fagfeltet fysiske aktivitet, kropp og bevegelse i barnehagen.

\section{Sammendrag av temanummerets fire artikler}

Den første artikkelen er skrevet av fagmiljøet i Sogndal. Forfattere er Kjersti Johannessen, Elisabeth Bjørnestad, Ada Kristine Ofrim Nilsen, Einar Ylvisåker og Merete Nornes-Nymark. Tittelen på artikkelen er «Associations for preschool 
environmental quality with outdoor time and moderate-to-vigorous physical activity in Norwegian preschools». Denne studien viser oss forholdet mellom barnehagebarns utetid, objektivt målt fysisk aktvitetsnivå (MVPA) og kvalitet (ulike egenskaper) i barnehagemiljø. Studien har fokus på hvordan egenskaper i barnehagemiljø kan fremme og begrense barns fysiske aktvitetsnivå, et tema som er sentralt for barns helse og generelle utvikling. Johannessen et al. innleder med hvor viktig det er å etablerere gode vaner for bevegelse og fysisk aktivitet tidlig i livet, og henviser til verdens helseorganisasjon (WHO) som anbefaler barn å være i minst 60 minutter med moderat til hard fysisk aktivitet hver dag. Artikkelens tema er viktig, spesielt $i$ en tid hvor samfunnstilbud er preget av teknologi og informasjon som fremmer stillesittende aktiviteter og som kan skape fysisk inaktive barn. Johannessen et al. benyttet akselerometer (ActiGraph GT3X +) på 358 barn i alder 2-6 år fra 29 ulike barnehageavdelinger og logg over utetiden som metode for å måle barns fysiske aktvitetsnivå. Samtidig ble kvalitet (ulike egenskaper) i barnehagemiljø vurdert ved bruk av Early Childhood Environment Rating Scale - Revised (ECERS-R). Resultater i denne studien viser sterk sammenheng mellom barnehagekvalitet og utetid, og svak sammenheng mellom barnehagekvalitet og fysisk aktvitetsnivå MVPA. Forfatterne diskuterer sentrale faktorer som angår rom og møblering, ansattes rutiner, kommunikasjon og interaksjoner som påvirker barns fysiske aktvitetsnivå. Konklusjoner er at barn registrert i avdelinger vurdert med høy kvalitet (ECERS-R), tilbrakte mindre tid ute og mindre tid i høy fysisk aktivitet. Forfatterne diskuterer betydningen av hvordan ulike egenskaper ved barnehagemiljø, som blant annet barnehagers sikkerhetsrutiner og praksis, kan begrense barns bevegelsesmuligheter. Studien til Johannesen et al. er viktig fordi den belyser forhold ved egenskaper i barnehagemiljøer og hvordan dette kan fremme og begrense barns fysiske aktvitetsnivå.

Den andre artikkelen er skrevet av forskere fra ulike forskermiljø i Norge. Tittel på denne artikkelen er «Innendørs risikofylt lek: Muligheter for spenning og variasjon i barnehagens lekemiljøer?" Forfatterne er Rasmus Kleppe, Ole Johan Sando og Ellen Beate Hansen Sandseter. Tema for denne artikkelen er risikofylt lek i barnehagens innemiljø. Studien tilfører noe nytt inn i barnehageforskningen fordi risikolek som oftest er forbundet med lek i utemiljø. Studien springer ut fra prosjektet EnCompetence (DMMH, 2017). Prosjektets mål har vært å utvikle ny kunnskap som kan fremme lek og bidra til høyere kompetanse i planlegging og utvikling av barnehagers fysiske lekemiljø. Prosjektet er utformet som et designeksperiment hvor forskere og barnehageansatte i samarbeid har utviklet, testet og evaluert kunnskap og intervensjoner gjennom en syklisk prosess. Prosjektet er gjennomført i nært samarbeid med tre barnehageeiere og ansatte i de deltakende barnehagene. Prosessen har vært delt inn i ulike faser, med observasjoner, kunnskapsutvikling og intervensjon, ny runde med observasjon og videre kunnskapsutvikling og formidling. Alle deltakende barnehager har gjennomført intervensjon, og i denne artikkelen undersøkes effekten av intervensjonen ved å sammenligne data fra T1 og T2. Kleppe et al. tar for seg forskningsspørsmålene om hva slags risikofylt lek som foregår i barnehagens 


\section{K. Bjørgen E̋ O. B. Lysklett}

innemiljø og hvor den foregår, og om hvordan en intervensjon påvirker risikofylt lek i innemiljøet. Metodisk er videoobservasjon benyttet av 65 barn i alderen 3-5 år, fra syv barnehager, i perioder hvor barna var frie til å leke som de selv ville. Basert på observasjonene i T1 ble det gjennomført en intervensjon for å styrke de eksisterende fysiske lekemiljøene. Intervensjonen ble utviklet og giennomført som et samarbeid mellom forskerne og ansatte i barnehagene. Effektene av intervensjonen ble observert i T2. Studien til Kleppe et al. viser at barn lekte risikofylt innendørs, særlig lek med høyde og boltrelek/lekeslåssing, og at den risikofylte leken hovedsakelig foregikk på tumleareal og i garderoben. Resultater knyttet til intervensjonen viste at barnehagene som etablerte et integrert tumleareal hadde en økning av risikofylt lek innendørs. I tillegg viser resultatene at både jenter, gutter og barn i ulike aldre tok i bruk tumlearealene til risikofylt lek etter intervensjonen. Denne studien er viktig med tanke på betydningen av hvordan fokus på endringer i barnehagemiljø, her innendørs, kan fremme mulighet for risikolek i innemiljø. Risikolek er forbudet med fysisk aktive barn, og av den grunn gir Kleppe et al. sin forskning et nytt blikk på hvordan ansatte i barnehagen kan fremme barns fysiske aktivitet gjennom tilrettelegging av risikolek i innemiljø.

I den tredje artikkelen er det sett på sammenhengen mellom barns motoriske ferdigheter og språkferdigheter. Tittel på artikkelen er «Relations between motor skills and language skills in toddler and preschool age». Studien er en del av det langsgående, tverrfaglige Stavanger-prosjektet The Learning Child (Reikerås et al., 2012), et samarbeid mellom Nasjonalt senter for leseopplæring og forskning ved Universitetet i Stavanger og Stavanger kommune. Elin Reikerås, Thomas Moser og Finn Egil Tønnessen undersøkte forholdet mellom språk og motoriske ferdigheter hos barn litt under tre år (2,9 år) og hos de samme barna to år etter (4,9 år). Dette er et interessant tema med høy relevans for barnehagen. Metoden de benyttet var data samlet av ansatte i norske barnehager gjennom strukturert observasjon under lek og daglige aktiviteter (autentisk vurdering). Måleinstrumentene TRAS Tidlig registrering av språkutvikling og EYMSC - Early years movement skills checklist for måling av motoriske ferdigheter ble benyttet. Resultatene viste sammenhenger mellom motoriske ferdigheter og språkferdigheter og støtter, og utfyller, tidligere forskning som indikerer sammenhenger mellom nivå på motoriske ferdigheter hos barn i 2-3-årsalderen og språkferdigheter i 4-5-årsalderen. Denne studien bidrar til viktig kunnskap om forholdet mellom motoriske ferdigheter og språkferdigheter som har betydning for pedagogisk praksis i barnehagen. Barns motoriske utvikling er ikke en uavhengig prosess, men har mangfoldige og komplekse relasjoner med flere kognitive utviklingsområder. Stavangermiljøets forskning har vist oss at det er lave til moderate sammenhenger mellom hverdags-motoriske ferdigheter og språkkunnskaper, og at sammenhengene er mer fremtredende for 5-åringene enn for 3-åringene. Implikasjoner er å fremme en aktivitets- og bevegelsesorientert pedagogikk som styrker barns motoriske kompetanse, og som samtidig støtter utvikling på andre utviklingsområder. Tilrettelegging av motorisk aktivitet i barnehagen kan bidra til 
øt mestring av utfordringer som involverer barnas egen kropp i fysiske og sosiale miljø. Disse erfaringene kan være avgjørende for barns generelle kognitive utvikling og læring, inkludert språk. Forfatterne viser til interessante diskusjoner om hvorfor motoriske ferdigheter ikke bare er et spørsmål om kroppslig og fysisk utvikling, men bør sees i integrert helhetlig pedagogisk tilnærming som adresserer alle utviklingsområder hos barnehagebarn.

Den fjerde og siste artikkelen i dette temanummeret belyser hvordan barn i barnehagen utvider og endrer sine bevegelsespraksiser. Lillian Pedersen og Vegard Fusche Moe har bidratt med artikkelen «The moment of play and movement: A qualitative study of children's playful shared movements». Studien undersøker gjennom observasjoner av åtte femåringer hva som kjennetegner barna sine lekende bevegelsesmøter på utelekeplassen, og hva som skjer når barna erfarer tilsynelatende nye og uventede bevegelser i disse møtene. Spørsmålet forfatterne stiller er hva som karakteriserer nye og uventede lekende bevegelsesmøter mellom barna og mellom barna og personalet på utelekeplassen i barnehagen. Studien viser oss at på lekeplassen kan barn være i bevegelse og leke fritt med hverandre. Det åpner opp for muligheter til at de kan utforske sine egne og hverandres bevegelsespraksiser.

Gjennom en kvalitativ tilnærming med observasjonsbeskrivelser av hva som skjer på utelekeplassen i barnehagen viser funnene at barna i sine lekende bevegelsesmønstre bruker vanemønstre til å skape kritiske «nå-øyeblikk» som introduserer barna til noe nytt og uventet. Forfatterne benytter et fenomenologisk og hermeneutisk perspektiv for å forklare barnas bevegelsespraksiser og endring av disse praksisene i barnehagens utemiljø. Teoretisk blir Daniel Sterns konsept nå-øyeblikk benyttet, noe som viser et interessant blikk på hvordan barn kan åpne opp for noe nytt, som skaper endring eller for å trekke seg bort fra situasjonen. Forfatterne beskriver hvordan følelser, inntoning og vitalitetsformer påvirker barnas lekende møter på utelekeplassen. Gjennom deskriptive analyser viser Pedersen og Moe situasjoner i uteleken hvor disse øyeblikkene åpnes av forestillinger, transformasjoner og spenning. I disse øyeblikkene kan barn være kreative og nysgjerrige, som kan føre til muligheter for å oppleve vekst i hvordan de bruker kroppen sin og stedet. Basert på disse funnene er det viktig å øke barnehagelærernes kunnskap om lekens egenverdi, samt om hvordan de voksne kan bevege seg for å skape lekne delte bevegelser. Denne studien viser oss interessante analyser av dynamiske skifter fra nå til øyeblikk av møter som oppstår i lekescenarier i utelekeplasser. Disse dynamiske skiftene kan være store og synlige, men ofte er de små og vanskelige å få øye på. Barn lever i disse dynamiske skiftene hele tiden, og opplever dem fra førstepersonsperspektiv i vennerelasjoner. Som voksne ser vi de dynamiske skiftene fra utsiden, for eksempel når barn plutselig blir dypt involvert og begeistret for en oppgave, eller når et barn blir utelatt. Studien konkluderer med at deltakerne i leken er emosjonelt tonet inn på hverandre, og at dette er avgjørende for at utvidelse av bevegelsespraksiser kan bli realiserte. Studien viser oss hvor viktig relasjoner og kommunikasjon mellom de lekende, både barna imellom og mellom barna og de voksne, er på utelekeplassen for barns utvidelse og endringer av sine bevegelsespraksiser. 


\section{K. Bjørgen E O. B. Lysklett}

\section{Avslutning}

Samlet sett dekker disse artiklene flere av temaområdene som fagmiljøet innenfor barnehageforskning og fysisk aktivitet, kropp og bevegelse er opptatt av. Artiklene viser til dagsaktuelle temaer og problemstillinger om kvaliteter ved barnehagemiljø og fysisk aktvitetsnivå hos barn, innemiljø og risikofylt lek, sammenhenger mellom barns motoriske ferdigheter og språkferdigheter, og hvordan barn i barnehagen utvider og endrer sine bevegelsespraksiser. Samtidig får vi innblikk i spennende og varierte metodiske fremgangsmåter og tilnærminger. Forfatterne viser til ulike forskningsdesign som intervensjonsforskning, langtidsstudie (longitudinell) og observasjoner, og til bruk av ulike standardiserte verktøy for å måle barns fysisk motoriske ferdigheter, fysisk aktivtetsnivå og til vurdering av miljøkvaliteter.

Vi takker artikkelforfatterne for deres bidrag, som hever kompleksiteten i forståelse av barnehagebarn og fysiske aktivitet, kropp og bevegelse. Vi ønsker i tillegg å rette en stor takk til fagfellene ved Nord universitetet, Høgskulen på Vestlandet, Universitetet i Stavanger, Universitetet i Agder, NTNU, Universitetet i Sørøst-Norge, OsloMet og fra DMMH, som har lest, vurdert og kommentert, både de trykte og de dessverre avviste artiklene. Uten dem hadde det ikke blitt noe temanummer. Tusen takk for vel gjennomført arbeid.

Trondheim, 12. desember 2020

Redaktører for temanummeret

Kathrine Bjørgen og Olav Bjarne Lysklett

\section{Om redaktørene}

Kathrine Bjørgen, ph.d., er førsteamanuensis i fysisk aktivitet og helse ved Dronning Mauds Minne Høgskole for barnehagelærerutdanning. Hennes doktorgrad fra NTNU (2017) er basert på avhandlingen Bevegelsesglede $i$ barnehagen - En kvalitativ studie av 3-5-åringers trivsel, involvering og fysiske aktivitet $i$ barnehagens ulike miljø. Hun har forsket på barns trivsel og involvering i fysisk lek spesielt rettet mot utemiljøet. Hun har skrevet flere artikler om trivsel i barnehagen, og en rekke bokkapitler som omhandler barns bevegelsesglede og bevegelseslek. For Bjørgens forskning se https://dmmh.no/om-dmmh/ansatte/kathrine-bjorgen-2

Olav B. Lysklett er dosent i fysisk aktivitet og helse ved Dronning Mauds Minne Høgskole for barnehagelærerutdanning. Han har arbeidet i universitets- og høgskolesystemet i snart 25 år og har i en årrekke forsket på natur- og friluftsbarnehager. I 2013 ga han ut boka Ute hele uka - Natur- og friluftsbarnehagen. Han forsker for tiden på barns motorikk og fysiske form, har skrevet en rekke artikler og bokkapitler og har gjort flere studier på ulike typer barnehager. For Lyskletts forskning se https://dmmh. no/om-dmmh/ansatte/olav-bjarne-ollis-lysklett-2 